\title{
Skala Zaufania do Przełożonego jako narzędzie do mierzenia zaufania do menedżerów
}

\begin{abstract}
Background: The aim of the study was operationalizing trust in supervisor concept and assesses the psychometric properties of the tool using to measure this construct. Material and Methods: Subjects were 804 employees from different organizations. The following measures were used: Perceived Supervisor Support Scale, Perceived Stress at Work Questionnaire, Grattitude Towards Organization Scale, Organizational Loyalty Scale and 2 measures - regarding intention to leave and job satisfaction. Results: Confirmed very good psychometric properties of Trust in Supervisor Scale. Factor analysis statistically confirmed the two dimensional structure of this measure inclusive benevolence and integrity factor containing 12 items and abilities as well as competences containing 8 items. The reliability of the Trust in Supervisor Scale was confirmed using the $\alpha$-Cronbach coefficient. The proof of the theoretical validity of this measure are its positive correlations with job satisfaction, loyalty and gratitude towards the organization as well as its negative relationships with the intend to quit organization and the level of stress. Conclusions: The obtained results confirm that the Trust in Supervisor Scale has a very good psychometric properties and may be used in practice to explore trust in mangers in organizations in Poland.
\end{abstract}

Keywords: trust in supervisor, psychometric properties, perceived supervisor support, job satisfaction, intend to quit organization 


\section{Wprowadzenie}

Z aufanie jako fenomen społeczny stanowi przedmiot badań wielu dziedzin nauki, takich jak zarządzanie, psychologia, socjologia, ekonomia, prawo czy medycyna. W psychologii pracy i organizacji kładzie się nacisk na identyfikację czynników sprzyjających budowaniu i kształtowaniu zaufania w relacjach pracownik-organizacja, pracownik-przełożony czy pracownik-współpracownicy ${ }^{1}$. Zaufanie jest podstawowym elementem, w oparciu o który dokonuje się wymiana społeczna ${ }^{2}$ pomiędzy podwładnym i przełożonym, sprzyjając budowaniu pozytywnych więzi w pracy oraz kształtowaniu długofalowej relacji między nimi. Zgodnie z dotychczasowymi wynikami badań zaufanie do przełożonego pełni istotną rolę w jakości wymiany między podwładnym a przełożonym (lider-member exchange) ${ }^{3}$.

Ważnym elementem budowania zaufania są predyspozycje osobowościowe ${ }^{4}$, kształtowane przez procesy socjalizacji ${ }^{5}$, a na późniejszych etapach rozwoju osobniczego modyfikowane lub utrwalane w wyniku doświadczeń życiowych. Ze względu na to, że zaufanie do przełożonego jest interpersonalną formą zaufania opartą na wzajemności i ma obustronny charakter, istotną rolę w budowaniu zaufania poza atrybutami podwładnego odgrywa charakter przełożonego, motywy jego postępowania, jego umiejętności oraz postawa względem podwładnego ${ }^{6}$.

Zgodnie z analizą literatury przedmiotu budowanie zaufania pracownika do menedżera odbywa się w oparciu o takie czynniki, jak jego podatność na zranienie ${ }^{7}$, wzajemność ${ }^{8}$ oraz jego oczekiwanie dotyczące pozytywnej postawy przełożonego ${ }^{9}$.

${ }^{1}$ G. Dietz, D.N. Hartog, Measuring trust inside organisations, „Personnel Review” 35/2006.

2 P. Blau, Exchange and power in social life, Wiley, New York 1964.

${ }^{3}$ C. Schriesheim, S. Castro, C. Cogliser, Leader-member exchange (LMX) research: A comprehensive review of theory, measurement, and data-analytic procedures, „Leadership Quarterly” 10/1999; S. Aryee, P.S. Budhwar, Z. Xiong Chen, Trust as a mediator of the relationship between organizational justice and work outcomes: Test of a social exchange model, „Journal of Organizational Behaviour” 23/2002; P. Neves, A. Caetano A., Social exchange processes in organizational change: The roles of trust and control, „Journal of Change Management” 4(6)/2006.

${ }^{4}$ R.C. Mayer, J.H. Davis, F.D. Schoorman, An integrative model of organizational trust, „Academy of Management Review” 20/1995; J.B. Rotter, A new scale for measurement of interpersonal trust, „Journal of Personality” 35(4)/1967.

${ }^{5}$ M.C. Clark, R.L. Payne, The nature and structure of workers'trust in management, ,Journal of Organisational Behavior" 18/1997.

${ }^{6}$ G. Dietz, D.N. Hartog, Measuring...

7 R.C. Mayer, J.H. Davis, F.D. Schoorman, An integrative model...

${ }^{8}$ D.E. Zand, Trust and managerial problem solving, „Administrative Science Quarterly” 17(2)/1972.

9 S.L. Robinson, Trust and breach of the psychological contract, „Administrative Science Quarterly” 41(4)/1996; R.E. Larzelere, T.L. Huston, The dyadic trust scale: Toward understanding interpersonal trust in close relationships, „Journal of Marriage and the Family” 42(3)1980. 
Podatność na zranienie jest decyzyjnym aspektem procesu zaufania ${ }^{10} \mathrm{i}$ dotyczy możliwości bycia skrzywdzonym i doświadczenia potencjalnie negatywnych skutków w wyniku działań podejmowanych przez przełożonego ${ }^{11}$. Jest ona przejawem ryzyka ${ }^{12}$, wyrażającego się w braku kontroli zachowań i postaw przełożonego jako potencjalnego źródła krzywdy ${ }^{13}$. Relacja ta ma asymetryczny charakter ze względu na władzę, status i hierarchię, stanowiąc o posiadaniu przez przełożonego przewagi w relacjach z podwładnym. Formalna zależność pracownika od menedżera sprawia, że jego funkcjonowanie w organizacji jest zależne od decyzji podejmowanych przez przełożonego.

Wzajemność zgodnie z teorią wymiany społecznej ${ }^{14}$ opiera się na dwustronności w relacji kształtowanej poprzez transakcje zachodzące między pracownikiem i menedżerem, obligując ich zgodnie z regułą wzajemności w przypadku otrzymania dobra do dokonania zadośćuczynienia drugiej stronie proporcjonalnego do tego, co się dostało, w celu wyrównania rachunków oraz spłacenia długu wdzięczności ${ }^{15}$. Dotychczasowe wyniki badań potwierdzają kluczową rolę zaufania dla jakości relacji między podwładnym i przełożonym opartej na mechanizmie wymiany społecznej ${ }^{16}$.

Oczekiwania podwładnego dotyczące pozytywnej postawy przełożonego względem niego opierają się na przekonaniu, że jest ona konsekwencją posiadanych przez przełożonego pewnych cech ${ }^{17}$. W związku z tym pracownik oczekuje od menedżera określonej, pozytywnej postawy względem siebie, u źródeł której, w jego ocenie, tkwią takie jego cechy, jak altruizm ${ }^{18}$, życzliwość czy szczerość ${ }^{19}$.

Ocena zaufania stosowana w miarach zaufania do przełożonego opiera się właśnie na domniemaniu podwładnego, że postawa przełożonego w stosunku do niego jest rezultatem posiadanych przez niego atrybutów ${ }^{20}$. Dla przykładu w koncepcji Pameli Shockley-Zalabak, Kathleen Ellis i Gaynelle Winograd ${ }^{21}$ są to kompetencje, otwartość, szczerość, troska o pracowników czy rzetelność, a u Murraya Clarka

${ }^{10}$ G. Dietz, D.N. Hartog, Measuring...

${ }_{11}$ T.H. Chiles, J.F. McMackin, Integrating variable risk preferences, trust, and transaction cost economics, „Academy of Management Review” 21(1)/1996;

${ }^{12}$ S.C. Currall, T.A. Judge, Measuring trust between organizational boundary role persons, „Organizational Behavior and Human Decision Processes” vol. 64, no. 2.

${ }^{13}$ D.E. Zand, Trust and managerial problem...; C. Argyris, Integrating the individual and the organization, John Wiley \& Sons, Inc., New York 1964.

${ }^{14}$ P. Blau, Exchange...

${ }^{15}$ A.W. Gouldner, The norm of reciprocity: A preliminary statement, „American Sociological Review” 25(2)/1960.

${ }^{16}$ C. Schriesheim, S. Castro, C. Cogliser, Leader-member exchange (LMX) research...

${ }_{17}$ G. Dietz, D.N. Hartog, Measuring...

18 T. Frost, D.V. Stimpson, N.R.C. Maughan, Some correlates of trust, „Journal of Psychology" 99(1)/1978.

${ }^{19}$ S.C. Currall, T.A. Judge, Measuring...

${ }^{20}$ G. Dietz, D.N. Hartog, Measuring...

${ }^{21}$ P. Shockley-Zalabak, K. Ellis, G. Winograd, Organizational trust: What it means, why it matters, „Organizational Development Journal” 18(4)/2000. 
i Roya Payne’a ${ }^{22}$ integralność, kompetencje, stałość zachowań, lojalność, otwartość oraz okazywanie szacunku.

Zgodnie z najlepiej ugruntowanym w literaturze przedmiotu modelem zaufania do przełożonego, którego autorami są Roger Mayer, James Davis i David Schoorman ${ }^{23}$, są to: umiejętności, życzliwość i integralność.

Umiejętności przełożonego w decydujący sposób wpływają na kształtowanie zaufania podwładnego wobec niego. Pracownik dokonuje oceny specyficznych umiejętności przełożonego charakterystycznych dla obszaru biznesowego, którym się zajmuje i jeśli ta ocena jest pozytywna, menedżerowi łatwiej jest zbudować autorytet w jego oczach, a tym samym zdobyć jego zaufanie.

Życzliwość obejmuje percepcję przez podwładnego pozytywnej orientacji przełożonego względem siebie, która zgodnie z jego przekonaniami opiera się na niewymuszonym czynieniu dobra bez oczekiwania przez niego wymiernych korzyści. Zakłada ona swoistego rodzaju więź między przełożonym i podwładnym. Menedżer w tej relacji występuje w roli mentora i jest to rezultat jego własnej inicjatywy wynikającej z motywacji wewnętrznej, a nie jakichkolwiek czynników zewnętrznych. Reasumując, jest to swoistego rodzaju akt dobrej woli, w ramach którego, w oczach podwładnego, przełożony prezentuje wobec niego życzliwą postawę.

Integralność dotyczy zestawu zasad i wartości stanowiących pewien standard postępowania przełożonego, a świadczących o jego przewidywalności, stałości jego zachowań czy równym traktowaniu wszystkich współpracowników. Przestrzeganie tych zasad przez przełożonego określa jego integralność. Na jej ocenę dokonywaną przez podwładnego ma wpływ spójność wcześniejszych działań przełożonego, wiarygodne informacje na jego temat otrzymywane od innych osób czy przekonanie, że posiada on silne poczucie sprawiedliwości, a jego działania są zgodne ze składanymi deklaracjami ${ }^{24}$.

W Polsce jest widoczny brak narzędzia do weryfikacji oceny zaufania do menedżerów, które z powodzeniem może być wykorzystywane w badaniach przedsiębiorstw, a na podstawie otrzymanych wyników budowany kapitał społeczny w organizacjach. Zaufanie w organizacjach jest bardzo pożądaną kulturowo cechą i powinno być skutecznie rozwijane i kształtowane wśród pracowników ${ }^{25}$. Szczególnie w Polsce, ze względu na deficyt zaufania społecznego ${ }^{26}$, istnieje duży potencjał rozwojowy do budowania tej cechy wśród polskich pracowników.

Celem przeprowadzonych badań było zaprezentowanie rzetelności, trafności wewnętrznej i trafności teoretycznej narzędzia do badania zaufania do przełożo-

${ }^{22}$ M.C. Clark, R.L. Payne, The nature and structure...

${ }^{23}$ R.C. Mayer, J.H. Davis, F.D. Schoorman, An integrative model...

${ }^{24}$ Ibidem.

${ }^{25}$ D. Gambetta, Can we trust trust?, w: D. Gambetta (red.), Trust...

${ }^{26}$ https://www.edelman.com/trust2017/ [26.02.2018]. 
nego. Rzetelność Skali Zaufania do Przełożonego była mierzona współczynnikiem $\alpha$-Cronbacha, a trafność wewnętrzną badano przy użyciu eksploracyjnej oraz konfirmacyjnej analizy czynnikowej.

Trafność teoretyczna przygotowanego narzędzia była weryfikowana przez skorelowanie jego wyników z miarami dobrostanu pracowników, takimi jak satysfakcja z pracy, stres doświadczany w pracy czy zamiar odejścia z organizacji. Weryfikowane były także zależności między rezultatem Skali Zaufania do Przełożonego a postrzeganym przez pracownika wsparciem otrzymywanym od przełożonego (Perceived Supervisor Support). Konstrukt ten w literaturze jest ujmowany jako kluczowy element budowania zaufania pracownika do przełożonego odzwierciedlający postawę przełożonego względem niego. Dodatkowo w ramach trafności teoretycznej sprawdzano, czy zaufanie do przełożonego jako istotny element wymiany społecznej między nim a jego podwładnym przełoży się na pozytywną postawę podległego pracownika, przejawiającą się wdzięcznością i lojalnością wobec organizacji.

Zaufanie do przełożonego jest jednym z elementów istotnych dla dobrostanu pracowników mierzonego przy użyciu różnych narzędzi ${ }^{27}$. Dotychczasowe wyniki badań potwierdzają istotną rolę zaufania do przełożonego dla przywiązania emocjonalnego pracowników ${ }^{28}$, ich satysfakcji z pracy ${ }^{29}$, zadowolenia z przełożonego ${ }^{30}$, redukcji stresu ${ }^{31}$, emocjonalnego wyczerpania oraz konfliktów interpersonalnych ${ }^{32}$, jak również zamiaru odejścia z organizacji3³. Można to wyjaśnić tym, iż pozytywne relacje z przełożonym oparte na zaufaniu dają podwładnemu możliwość spełnia-

27 J.A. Colquitt, B.A. Scott, J.A. LePine, Trust, trustworthiness, and trust propensity: A meta-analytic test of their unique relationships with risk taking and job performance, „Journal of Applied Psychology” 92/2007; K.T. Dirks, D.L. Ferrin, Trust in leadership: Metaanalytic findings and implications for research and practice, ,Journal of Applied Psychology” 87/2002.

${ }^{28}$ P. Neves, A. Caetano, Social exchange processes...

${ }^{29}$ G.A. Rich, The sales manager as a role model: Effects on trust, job satisfaction, and performance of salespeople, „Academy of Marketing Science” 25(4)/1997; N. Pomirleanu, B. John-Mariadoss, The influence of organizational and functional support on the development of salesperson job satisfaction, „Journal of Personal Selling and Sales Management” 35(1)/2015; J.P. Mulki, F. Jaramillo, W.B. Locander, Effects of ethical climate and supervisory trust on salesperson's job attitudes and intentions to quit, „,Journal of Personal Selling and Sales Management” 86(5)/2006.

${ }^{30}$ J.P. Mulki, W.B. Locander, G.W. Marshall, E.G. Harris, J. Hensel, Workplace isolation, salesperson commitment, and job performance, „Journal of Personal Selling \& Sales Management” 28(1)/2008; H.H. Tan, C.S.F. Tan, Toward the differentiation of trust in supervisor and trust in organization, „Genetic, Social, and General Psychology Monographs” 126(2)/2000.

${ }^{31}$ K.T. Liou, Role stress and job stress among detention care workers, „Criminal Justice and Behavior" vol. 22(4), 1995.

32 J.P. Mulki, F. Jaramillo, W.B. Locander, Effects of Ethical Climate and Supervisory Trust on Salesperson's Job Attitudes and Intentions to Quit, „Journal of Personal Selling \& Sales Management” 26(1)/2006.

33 J.P. Mulki, F. Jaramillo, W.B. Locander, Effects of ethical climate... 
nia w środowisku pracy potrzeb o charakterze społeczno-emocjonalnym, takich jak potrzeba bezpieczeństwa, uznania, szacunku czy emocjonalnego wsparcia ${ }^{34}$, czego konsekwencją jest odczuwanie przez niego dobrostanu. W badaniach przeprowadzonych przez Alex Ning Li i Hwee Hoon $\operatorname{Tan}^{35}$ na menedżerach z banku zaufanie do przełożonego było źródłem poczucia bezpieczeństwa psychicznego oraz dostępności psychologicznej pracowników. Spodziewano się, że zaufanie do przełożonego będzie pozytywnie związane z satysfakcją z pracy i negatywnie skorelowane ze stresem doświadczanym w pracy oraz zamiarem odejścia z organizacji.

Również postrzegane przez podwładnego wsparcie otrzymywane od przełożonego jest pozytywnym korelatem zaufania do jego osoby. Konstrukty te nie są ze sobą tożsame, choć są do siebie podobne, gdyż zarówno jeden, jak i drugi odwołują się do postawy przełożonego wobec podwładnego. Zgodnie z dotychczasowymi rezultatami badań wsparcie przełożonego sprzyja budowaniu zaufania podwładnego do jego osoby, stanowiąc podstawę, na której kształtuje się więź między nimi, opartą na zaufaniu ${ }^{36}$. Zakładano, że zaufanie do przełożonego będzie pozytywnie związane z postrzeganym wsparciem otrzymywanym od przełożonego.

Zgodnie z teorią wsparcia organizacyjnego ${ }^{37}$, która teorię wymiany społecznej ${ }^{38}$ przenosi na grunt relacji pracownik-organizacja, a w ramach której organizacja jest utożsamiana z przełożonym jako jej reprezentantem ${ }^{39}$, pracownik kierując się regułą wzajemności ${ }^{40}$, powinien być wdzięczny organizacji za wsparcie otrzymywane od przełożonego, odpłacając się jej lojalnością. Rezultaty badań Marcina Wnuka ${ }^{41}$ potwierdzają, że postrzegane wsparcie otrzymywane od przełożonego jest predyktorem wdzięczności oraz lojalności wobec organizacji. Założono, że zaufanie pracownika do menedżera zgodnie z regułą wzajemności ${ }^{42}$ będzie wpływało na jego poczucie wdzięczności wobec organizacji, którą przełożony uosabia, oraz powodowało u niego potrzebę odpłacenia się poprzez lojalną postawę względem niej. W związku z tym oczekiwano, że zaufanie do przełożonego będzie pozytywnie związane z wdzięcznością i lojalnością wobec organizacji.

${ }^{34}$ S. Armeli, R. Eisenberger, P. Fasolo, P. Lynch, Perceived organizational support and police performance: The moderating influence of socio-emotional needs, „Journal of Applied Psychology” 83/1998.

${ }_{35}$ A.N. Li, H.H. Tan, What happens when you trust your supervisor? Mediators of individual performance in trust relationships, „Journal of Organizational Behavior” 34(3)/2013.

${ }^{36}$ K.T. Dirks, D.L. Ferrin, Trust in leadership: Metaanalytic findings and implications for research and practice, „Journal of Applied Psychology” 87/2002.

${ }^{37}$ R. Eisenberger, R. Hungtington, S. Hutchison, D. Sowa, Perceived organizational support, „Journal of Applied Psychology” 71(3)/1986.

${ }^{38}$ P. Blau, Exchange...

${ }^{39}$ H. Levinson, Reciprocation: The relationship between man and organization, „Administrative Science Quarterly” 9(4)/2001.

${ }^{40}$ A.W. Gouldner, The norm of reciprocity...

${ }^{41}$ M. Wnuk, Wdzięczność i lojalność wobec organizacji jako istotne elementy wymiany pracownik-organizacja, „Zarządzanie Zasobami Ludzkimi” 118(5)/ 2017.

${ }^{42}$ C. Argyris, Integrating... 


\section{Metodyka badań}

\section{A. Opis grupy badanej}

W badaniu wzięło udział 804 pracowników zatrudnionych w różnych organizacjach mających swoją siedzibę na terenie Polski. Było ono anonimowe i dobrowolne. W badaniach uczestniczyło 58,1\% kobiet oraz 41,9\% mężczyzn. Średni staż pracy uczestników badań wyniósł 7,14 lat $(S D=9,36)$, średnie zatrudnienie w aktualnym miejscu pracy 3,97 lat $(S D=6,59)$, a średni wiek 28,05 lat $(S D=10,27)$.

\section{B. Narzędzia badawcze}

Zamiar odejścia z organizacji był mierzony za pomocą narzędzia składającego się z trzech pytań ${ }^{43}$. Badani odpowiadali na 5-stopniowej skali Likerta - od „Zdecydowanie się nie zgadzam” do „Zdecydowanie się zgadzam”. Rzetelność tej miary weryfikowana współczynnikiem $\alpha$-Cronbacha wyniosła 0,89 .

Wsparcie otrzymywane od przełożonego było mierzone za pomocą Skali Postrzeganego Wsparcia Przełożonego składającej się z trzech pytań ${ }^{44}$. Badani udzielali odpowiedzi na 5-stopniowej skali - od „Zdecydowanie się nie zgadzam” do „Zdecydowanie się zgadzam”. Rzetelność tej miary wyniosła $\alpha$-Cronbacha = 0,90.

Wdzięczność wobec organizacji była weryfikowana przy użyciu Skali Wdzięczności wobec Organizacji ${ }^{45}$. Składa się ona z dwóch wymiarów. W badaniach użyto czterech z ośmiu stwierdzeń dotyczących wymiaru wdzięczności warunkowej opartej na regule wzajemności. Na zadane pytania odpowiedzi były udzielane na 5-stopniowej skali - od „Zdecydowanie się nie zgadzam” do „Zdecydowanie się zgadzam”. Rzetelność wyniosła $\alpha$-Cronbacha $=0,87$.

Lojalność w odniesieniu do organizacji była badana Skalą Lojalności wobec Organizacji składającą się z dwóch czynników. Pierwszy z nich to dbanie o pozytywny wizerunek organizacji, a drugi to skłonność do poświęceń i wyrzeczeń na rzecz organizacji ${ }^{46}$. Wybrano krótką wersję skali składającą się z ośmiu pytań (cztery dla każdego z wymiarów). Na zadane pytania badani odpowiadali na 5-stopniowej skali Likerta - od „Zdecydowanie się nie zgadzam” do „Zdecydowanie się zgadzam”.

${ }^{43}$ I. Yücel, Examining the relationships among job satisfaction, organizational commitment, and turnover intention: An empirical study, „International Journal of Business and Management” 7/2012.

${ }^{44}$ R. Eisenberger, R. Hungtington, S. Hutchison, D. Sowa, Perceived organizational...

${ }^{45}$ M. Wnuk, Psychometric evaluation of the Gratitude Toward Organization Scale, „Central European Management Journal” 28(2)/2020.

${ }^{46}$ T. Chirkowska-Smolak, M. Wnuk, Lojalność pracowników wobec organizacji - operacjonalizacja pojęcia oraz weryfikacja psychometryczna Skali Lojalności Wobec Organizacji - badania pilotażowe, „Organizacja i Kierowanie” 183(4)/2018. 
Dla wymiaru dbania o pozytywny wizerunek organizacji odnotowano rzetelność $\alpha$-Cronbacha $=0,87$, a dla wymiaru skłonność do poświęceń i wyrzeczeń na rzecz organizacji $\alpha$-Cronbacha $=0,87$.

Satysfakcja z pracy była mierzona stwierdzeniem „Generalnie lubię tu pracować”. Na zadane pytanie badani odpowiadali na 7-stopniowej skali - od „Zdecydowanie się nie zgadzam” do „Zdecydowanie się zgadzam”.

Do badania natężenia stresu w pracy użyto Kwestionariusza Postrzeganego Stresu w Pracy. Na zadane pytania badani odpowiadali na 5-stopniowej skali - od „Nigdy” do „Prawie Zawsze”47. Użyto 5 z 10 pytań tej miary składających się na jeden czynnik poprzez wybór pytań o najwyższych ładunkach czynnikowych. Rzetelność tego narzędzia wyniosła $\alpha$-Cronbacha $=0,89$.

\section{Konstrukcja Skali Zaufania do Przełożonego}

Narzędzie mierzące zaufanie do przełożonego powstało w oparciu o najlepiej merytorycznie ugruntowany w literaturze model zaufania do przełożonego autorstwa Mayer, Davis i Schoorman ${ }^{48}$, zgodnie z którym składa się ono z trzech elementów w postaci życzliwości, integralności oraz umiejętności i stanowi gotowość podwładnego do narażenia się na doznanie krzywdy od przełożonego, bez możliwości kontroli i wpływu na jego postawę względem siebie. Oznacza to, że immanentną cechą budowania relacji opartej na zaufaniu jest ryzyko, które w relacji przełożony-podwładny ze względu na władzę posiadaną przez menedżera podejmuje podległy mu pracownik. Ryzyko to wiąże się z potencjalnymi skutkami negatywnej postawy przełożonego w postaci doznania przez podwładnego krzywdy. Wymiar umiejętności zgodnie z założeniami autorów tej koncepcji oraz dodatkowo dla oddania pełniejszego zakresu semantycznego w języku polskim został odzwierciedlony poprzez umiejętności i kompetencje ${ }^{49}$. Umiejętności i kompetencje nie odnosiły się do specyficznych dla danego obszaru biznesowego kwalifikacji, ale dotyczyły głównie umiejętności menedżerskich, takich jak motywowanie, rozwiązywanie problemów, zarządzanie zasobami ludzkim czy realizacja celów. Było to wynikiem założenia, że zaufanie do przełożonego i jego autorytet opierają się głównie na jego umiejętnościach menedżerskich, stanowiących immanentną cechę pełnionej przez niego roli. Umiejętności menedżerskie w przeciwieństwie do eksperckich są warunkiem sine qua non każdego menedżera i bez nich trudno zbudować do siebie zaufanie współpracowników. Łatwo wyobrazić sobie sytuację, w której menedżer jest dobrym ekspertem, nie potrafi jednak zarządzać ludźmi lub ma przeciętne umiejętności w danym obszarze, ale jest świetnym zarządzającym,

${ }^{47}$ T. Chirkowska-Smolak, J. Grobelny, Konstrukcja i wstępna analiza psychometryczna Kwestionariusza Postrzeganego Stresu w Pracy (PSwP), „Czasopismo Psychologiczne” 22(1)/2016.

${ }^{48}$ R.C. Mayer, J.H. Davis, F.D. Schoorman, An integrative model...

${ }^{49}$ Ibidem. 
co sprawia, że pewne luki kompetencyjne i braki w wiedzy związane z dziedziną, którą się zajmuje, zostają zepchnięte na dalszy plan.

Na podstawie powyższych założeń przygotowano listę pytań w formie krótkich i zrozumiałych 50 stwierdzeń, spośród których trzy miały formę przeczącą. Odpowiedzi na zadane pytania były udzielane na 5-stopniowej skali Likerta - od „Zdecydowanie zgadzam się”, „Zgadzam się”, „Trudno powiedzieć”, po „Nie zgadzam się” i „Zdecydowanie nie zgadzam się”.

Poszczególne pozycje kwestionariusza zostały następnie poddane weryfikacji językowej i treściowej przez sędziego kompetentnego, będącego psychologiem, oraz studentów piątego roku psychologii. W rezultacie powstała wstępna wersja narzędzia składająca się z 50 stwierdzeń. Na każde pytanie przypadało około szesnastu uczestników badań, spełniając w tym względzie kryteria zawarte w literaturze przedmiotu ${ }^{50}$.

\section{Wyniki}

\section{A. Trafność wewnętrzna}

Uzyskane dane dotyczące 804 badanych zostały podzielone na dwa równoliczne zbiory. Pierwszy z nich użyto do przeprowadzenia eksploracyjnej analizy czynnikowej (EFA), natomiast na drugim zastosowano konfirmacyjną analizę czynnikową (CFA). Posłużył on również do weryfikacji trafności teoretycznej Skali Zaufania do Przełożonego.

\section{B. Analiza eksploracyjna}

Przygotowana wersja narzędzia została poddana eksploracyjnej analizie czynnikowej przeprowadzonej metodą głównych składowych przy użyciu rotacji promax. Test adekwatności doboru próby Kaisera-Mayera-Olkina wyniósł 0,965, a test sferyczności Bartletta wyniósł $\mathrm{Chi}^{2} \approx 6235,02$, df $=190, \mathrm{p}<0,01$, co oznaczało, że próba została właściwie dobrana.

Wyodrębnione czynniki wyjaśniały 65,3\% wariancji. Pierwszy czynnik o nazwie Życzliwość i integralność wyjaśniał 57,4\%, a drugi, Umiejętności i kompetencje - 7,9\% wariancji tego narzędzia. Do końcowej wersji skali zaliczono pozycje testowe o najwyższej mocy dyskryminacyjnej, czyli takie, które z jednej strony wysycały jeden czynnik w stopniu nie mniejszym niż 0,5, równocześnie wysycając drugi z wyróżnionych czynników w stopniu nie większym niż 0,2. Wyselekcjonowane stwierdzenia przyporządkowane do danego czynnika miały

50 E. Hornowska, Testy psychologiczne teoria i praktyka, Wydawnictwo Naukowe Scholar, Warszawa 2017. 
korelować z jego wynikiem na poziomie nie mniejszym niż 0,7. Końcowa wersja narzędzia obejmowała 20 pytań. W skład pierwszego wymiaru weszło 12 pytań, natomiast drugi zawierał 8 pytań.

Wartości współczynników korelacji między poszczególnymi stwierdzeniami z wymiaru Życzliwość i integralność a jego wynikiem ogólnym wyniosły od 0,71 do 0,86. Analogicznie wartości współczynników korelacji między pytaniami wchodzącymi w skład wymiaru Umiejętności i kompetencje a jego wynikiem ogólnym plasowały się w przedziale od 0,71 do 0,85 (tab. 1). Wartości ładunków czynnikowych wyodrębnionych w ramach analizy czynnikowej stwierdzeń Skali Zaufania do Przełożonego były satysfakcjonujące (tab. 1). Pytania dotyczące wymiaru Życzliwość i integralność wysycały go w zakresie od 0,54 do 0,95, wysycając równocześnie drugi czynnik tego narzędzia w stopniu mniejszym niż 0,2. Również pytania dotyczące wymiaru Umiejętności i kompetencje wysycały go w zakresie od 0,69 do 0,84, a wyniki dla dwóch stwierdzeń zaliczonych do tego wymiaru, które wysycały najsilniej drugi czynnik, wyniósł 0,2. Statystyki opisowe Skali Zaufania do Przełożonego oraz jej poszczególnych wymiarów oraz wartość współczynnika korelacji r-Persona między wyróżnionymi wymiarami Skali Zaufania do Przełożonego przedstawiono w tabeli 2.

Tabela 1. Ładunki czynnikowe Skali Zaufania do Przełożonego oraz wartości współczynników korelacji (r-Pearsona) między stwierdzeniami Skali Zaufania do Przełożonego a wynikami jej poszczególnych wymiarów $(\mathrm{N}=804)$

\begin{tabular}{|l|c|c|c|c|}
\hline \multirow{2}{*}{ Pytania Skali Zaufania do Przełożonego } & \multicolumn{2}{|c|}{ Składowa } & \multicolumn{2}{|c|}{ Składowa } \\
\cline { 2 - 5 } & 1 & 2 & 1 & 2 \\
\hline Mój przełożony to osoba godna zaufania. & $\mathbf{0 , 7 6}$ & 0,12 & $\mathbf{0 , 8 4 *}$ & \\
\hline $\begin{array}{l}\text { W rozmowach ze mną mój przełożony } \\
\text { jest ze mną szczery. }\end{array}$ & $\mathbf{0 , 9 5}$ & $-0,15$ & $\mathbf{0 , 8 3 *}$ & \\
\hline $\begin{array}{l}\text { Mój przełożony stara się traktować wszystkich } \\
\text { równo. }\end{array}$ & $\mathbf{0 , 7 1}$ & 0,11 & $\mathbf{0 , 7 9 *}$ & \\
\hline Mój przełożony traktuje mnie sprawiedliwie. & $\mathbf{0 , 7 8}$ & 0,06 & $\mathbf{0 , 8 2 *}$ & \\
\hline $\begin{array}{l}\text { Jeśli mam problem w pracy, mogę się z nim } \\
\text { zwrócić do mojego przełożonego. }\end{array}$ & $\mathbf{0 , 7 1}$ & 0,12 & $\mathbf{0 , 8 0 *}$ & \\
\hline Mój przełożony jest uczciwy względem mnie. & $\mathbf{0 , 9 2}$ & $-0,07$ & $\mathbf{0 , 8 6 *}$ & \\
\hline Mój przełożony dotrzymuje obietnic. & $\mathbf{0 , 7 9}$ & 0,04 & $\mathbf{0 , 8 1 *}$ & \\
\hline $\begin{array}{l}\text { Mój przełożony nie zataja przede mną ważnych } \\
\text { informacji. }\end{array}$ & $\mathbf{0 , 9 1}$ & $-0,17$ & $\mathbf{0 , 7 6 *}$ & \\
\hline
\end{tabular}




\begin{tabular}{|c|c|c|c|c|}
\hline $\begin{array}{l}\text { Mój przełożony to osoba zasługująca } \\
\text { na szacunek. }\end{array}$ & 0,70 & 0,13 & $0,80 *$ & \\
\hline Mój przełożony dba tylko o siebie. & 0,69 & 0,14 & $\mathbf{0 , 8 1 *}$ & \\
\hline $\begin{array}{l}\text { Mój przełożony nie interesuje się potrzebami } \\
\text { swoich pracowników. }\end{array}$ & 0,54 & 0,19 & $0,71^{*}$ & \\
\hline Mój przełożony nadużywa władzy. & 0,68 & 0,07 & $0,74 *$ & \\
\hline $\begin{array}{l}\text { Mój przełożony posiada dużą wiedzę z obszaru, } \\
\text { którym się zajmuje. }\end{array}$ & $-0,16$ & 0,74 & & $0,84 *$ \\
\hline $\begin{array}{l}\text { Mój przełożony potrafi skutecznie rozwiązywać } \\
\text { problemy. }\end{array}$ & 0,05 & $\mathbf{0 , 8 0}$ & & $0,85^{*}$ \\
\hline $\begin{array}{l}\text { Mój przełożony jest właściwą osobą } \\
\text { na właściwym miejscu. }\end{array}$ & 0,20 & 0,69 & & $0,84 *$ \\
\hline $\begin{array}{l}\text { W swojej pracy mój przełożony postępuje } \\
\text { jak prawdziwy profesjonalista. }\end{array}$ & 0,20 & 0,69 & & $0,79 *$ \\
\hline Mój przełożony potrafi skutecznie motywować. & 0,05 & 0,84 & & $0,80^{*}$ \\
\hline $\begin{array}{l}\text { Mój przełożony potrafi szybko podejmować } \\
\text { właściwe decyzje. }\end{array}$ & 0,02 & 0,78 & & $0,82^{*}$ \\
\hline $\begin{array}{l}\text { W swoich działaniach mój przełożony wykazuje } \\
\text { się właściwymi umiejętnościami w zarządzaniu } \\
\text { ludźmi. }\end{array}$ & $-0,03$ & 0,84 & & $0,85^{*}$ \\
\hline $\begin{array}{l}\text { Mój przełożony potrafi skutecznie realizować } \\
\text { cele. }\end{array}$ & 0,13 & 0,84 & & $0,71^{*}$ \\
\hline
\end{tabular}

$* \mathrm{p} \leq 0,01$

Źródło: opracowanie własne.

Tabela 2. Statystyki opisowe oraz wartość współczynnik korelacji r-Pearsona między wymiarami Skali Zaufania do Przełożonego $(\mathrm{N}=804)$

\begin{tabular}{|l|c|c|c|c|}
\hline \multicolumn{1}{|c|}{ Czynnik } & min.-maks. & $\mathrm{M} \pm \mathrm{SD}$ & $\begin{array}{c}\text { Rzetelność } \\
\text { Cronbacha }\end{array}$ & $\begin{array}{c}\text { Życzliwość } \\
\text { i integralność }\end{array}$ \\
\hline Zaufaniale do Przełożonego & $20-100$ & $71,89 \pm 14,66$ & 0,96 & \\
\hline Życzliwość i integralność & $12-60$ & $43,03 \pm 9,34$ & 0,94 & \\
\hline Umiejętności i kompetencje & $8-40$ & $28,85 \pm 6,20$ & 0,93 & $0,77^{*}$ \\
\hline
\end{tabular}

** p $\leq$ 0,01, min. - wartość minimalna, maks. - wartość maksymalna, M - średnia, SD - odchylenie standardowe. 


\section{Analiza konfirmacyjna}

Kolejnym etapem było sprawdzenie trafności wewnętrznej Skali Zaufania do Przełożonego przy użyciu analizy równań strukturalnych metodą największego prawdopodobieństwa. Do weryfikacji modelu zastosowano następujące wskaźniki dopasowania modelu: normalizowany indeks dopasowania (Normed Fit Index - NFI), wskaźnik dobroci dopasowania (Goodness of Fit Index - GFI), indeks dopasowania porównawczego (Comparative Fit Index - CFI) i średni błąd aproksymacji (Root Mean Square Error of Approximation - RMSEA).

Uzyskane wartości RMSEA $=0,032[90 \%(0,024 ; 0,038)]$, NFI $=0,98$, GFI $=0,97$, CFI $=0,99$, statystyki Chi $^{2}=203,37$; $d=115 ; \mathrm{p}=0,001($ CMIN/ $\mathrm{DF}=1,80$ ) potwierdziły dobre dopasowanie modelu. Normalizowany indeks dopasowania (NFI) przewyższał zadowalający poziom 0,9, GFI - 0,9 i CFI - 0,93 Również wartość wskaźnika RMSEA znalazła się poniżej wartości granicznej, stanowiącej o idealnym dopasowaniu modelu i wynoszącej $0,05^{52}$.

\section{Trafność teoretyczna}

Trafność teoretyczna Skali Zaufania do Przełożonego była weryfikowana poprzez jej związki z takimi zmiennymi, jak postrzegane wsparcie otrzymywane od przełożonego, satysfakcja z pracy, chęć odejścia z organizacji, poziom stresu w pracy, jak również wdzięczność oraz lojalność wobec organizacji.

Współczynniki korelacji r-Persona między wynikiem Skali Zaufania do Przełożonego a miarami służącymi do weryfikacji jej trafności teoretycznej przedstawiono w tabeli 3. Wynik Skali Zaufania do Przełożonego korelował pozytywnie z satysfakcją z pracy oraz lojalnością i wdzięcznością wobec organizacji. Zanotowano ujemne korelacje między tą miarą a chęcią odejścia z organizacji, stresem doświadczanym w pracy, wiekiem, stażem pracy oraz długością zatrudnienia w aktualnym miejscu pracy.

Sprawdzano, czy płeć jest zmienną różnicującą badanych w odniesieniu do zaufania do przełożonego. Zgodnie z otrzymanymi wynikami kobiety i mężczyźni nie różnią się między sobą poziomem zaufania do przełożonego $(t=-1,05, p=0,29)$ oraz dwiema jego składowymi w postaci Życzliwości i integralności $(t=-0,51$, $p=0,60)$, jak również Umiejętności i kompetencji $(t=-1,71, p=0,09)$.

${ }^{51}$ B.M. Byrne, Structural equation modeling with EQS and EQS/Windows, Sage Publications, Thousand Oaks 1994.

52 J.H. Steiger, Structural model evaluation and modification: An interval estimation approach, „Multivariate Behavioral Research” 25(2)/1990. 
Tabela 3. Korelacje (r-Pearsona) między Skalą Zaufania do Przełożonego a wybranymi miarami zastosowanymi do weryfikacji trafności teoretycznej (N=804)

\begin{tabular}{|l|c|c|c|}
\hline $\begin{array}{l}\text { Miary użyte do weryfikacji } \\
\text { trafności teoretycznej }\end{array}$ & $\begin{array}{c}\text { Zaufanie do } \\
\text { przełożonego }\end{array}$ & $\begin{array}{c}\text { Życzliwość } \\
\text { i integralność }\end{array}$ & $\begin{array}{c}\text { Umiejętności } \\
\text { i kompetencje }\end{array}$ \\
\hline Chęć odejścia z organizacji & $-0,44^{* *}$ & $-0,42^{* *}$ & $-0,41^{* *}$ \\
\hline Satysfakcja z pracy & $0,52^{* *}$ & $0,49^{* *}$ & $0,45^{* *}$ \\
\hline Poziom stresu & $-0,50^{* *}$ & $-0,46^{* *}$ & $-0,43^{* *}$ \\
\hline $\begin{array}{l}\text { Wsparcie otrzymywane } \\
\text { od przełożonego }\end{array}$ & $0,85^{* *}$ & $0,81^{* *}$ & $0,80^{* *}$ \\
\hline $\begin{array}{l}\text { Wdzięczność } \\
\text { wobec organizacji }\end{array}$ & $0,61^{* *}$ & $0,58^{* *}$ & $0,57^{* *}$ \\
\hline $\begin{array}{l}\text { Skłonność do poświęceń } \\
\text { na rzecz organizacji }\end{array}$ & $0,21^{* *}$ & $0,16^{* *}$ & $0,25^{* *}$ \\
\hline $\begin{array}{l}\text { Dbanie o wizerunek } \\
\text { organizacji }\end{array}$ & $0,34^{* *}$ & $0,31^{* *}$ & $0,35^{* *}$ \\
\hline Wiek & $-0,09$ & $-0,11^{*}$ & $-0,07$ \\
\hline Staż pracy ogółem & $-0,10^{*}$ & $-0,11^{*}$ & $-0,07$ \\
\hline $\begin{array}{l}\text { Długość zatrudnienia } \\
\text { w aktualnej organizacji }\end{array}$ & $-0,07$ & $-0,08$ & $-0,05$ \\
\hline
\end{tabular}

${ }^{*} \mathrm{p} \leq 0,05 ; * * \mathrm{p} \leq 0,01$

Źródło: opracowanie własne.

\section{Omówienie}

Przeprowadzone badania potwierdziły bardzo dobre właściwości psychometryczne Skali Zaufania do Przełożonego. Zgodnie z otrzymanymi wynikami narzędzie to posiada zadowalającą trafność wewnętrzną weryfikowaną przy użyciu eksploracyjnej oraz konfirmacyjnej analizy czynnikowej. W porównaniu z modelem Mayera, Davis i Schoormana ${ }^{53}$, na którym opierano się, uzyskano dwu-, a nie trzyczynnikowe rozwiązanie. Jeden z otrzymanych czynników o nazwie Umiejętności i kompetencje okazał się być tożsamy z czynnikiem Umiejętności wyodrębnionym w ramach koncepcji zaufania do przełożonego, zaproponowanej przez tych autorów $^{54}$. Różnica między modelem Mayera, Davis i Schoormana ${ }^{55}$ a otrzymanymi rezultatami odnosiła się do tego, że w wyniku analizy czynnikowej nie otrzymano dwóch oddzielnych wymiarów o nazwie Życzliwość oraz Integralność, ale jeden wymiar, w ramach którego znalazły się pytania, które były przyporządkowane zarówno do pierwszego, jak i drugiego z nich.

\footnotetext{
${ }^{53}$ R.C. Mayer, J.H. Davis, F.D. Schoorman, An integrative model...

54 Ibidem.

${ }^{55}$ Ibidem.
} 
Skala Zaufania do Przełożonego składa się z dwóch wymiarów: Umiejętności i kompetencje oraz Życzliwość i integralność. Odzwierciedleniem umiejętności i kompetencji przełożonego jest odpowiednie motywowanie pracowników, podejmowanie właściwych decyzji, skuteczne rozwiązywanie problemów, skuteczne realizowanie celów oraz posiadanie dużej wiedzy w dziedzinie, którą się zajmuje. Życzliwość i integralność przełożonego przejawia się w jego uczciwości, szczerości, otwartości, dotrzymywaniu obietnic, sprawiedliwym traktowaniu czy dbaniu o potrzeby podwładnych. Z jednej strony oba wyróżnione czynniki silnie ze sobą korelowały, co mogłoby być przesłanką do uznania ich za tożsame lub stanowiące przejaw tego samego wymiaru, a nie dwóch różnych czynników składających się na jedną zmienną. Z drugiej strony, zarówno eksploracyjna, jak i konfirmacyjna analiza czynnikowa dowiodły, że stwierdzenia wchodzące w skład jednego z wymiarów Skali Zaufania do Przełożonego tylko w minimalnym stopniu wysycały drugi czynnik tej miary, co świadczy o tym, że obie wyróżnione podskale są odrębnymi bytami.

Rzetelność Skali Zaufania do Przełożonego okazała się satysfakcjonująca. Otrzymana wartość współczynnika $\alpha$-Cronbacha, która przekroczyła 0,9, była świadectwem wysokiego poziomu spójności pozycji testowych. Potwierdzono trafność teoretyczną Skali Zaufania do Przełożonego. Zgodnie z dotychczasowymi rezultatami badań jej wynik korelował z zastosowanymi miarami dobrostanu, takimi jak satysfakcja z życia ${ }^{56}$, chęć odejścia z organizacji ${ }^{57}$ czy stres doświadczany $\mathrm{w}$ pracy ${ }^{58}$. Był to dowód na to, że zaufanie do przełożonego odgrywa istotną rolę w kształtowaniu dobrostanu pracowników.

Zgodnie z poczynionymi założeniami zanotowano także pozytywne związki między zaufaniem do przełożonego a wdzięcznością oraz lojalnością wobec organizacji. Było to świadectwo istotnej roli, jaką zaufanie do przełożonego odgrywa dla wymiany społecznej ${ }^{59}$ między pracownikiem a organizacją, w ramach której organizacja jest reprezentowana przez przełożonego $0^{60}$, a podwładny w oparciu o zaufanie do przełożonego wyraża wdzięczność wobec organizacji i odpłaca się jej lojalnością poprzez dbanie o jej wizerunek oraz skłonność do poświęceń na jej rzecz. Było to również potwierdzenie wcześniejszych wyników badań świadczących o tym, że zaufanie do przełożonego jest istotnym elementem w kształtowaniu pozytywnej postawy w pracy niezależnie od stosowanych wskaźników i miar ${ }^{61}$.

${ }^{56}$ G.A. Rich, The sales manager...; N. Pomirleanu, B. John-Mariadoss, The influence of organizational...; J.P. Mulki, F. Jaramillo, W.B. Locander, Effects of ethical climate...

57 J.P. Mulki, F. Jaramillo, W.B. Locander, Effects of ethical climate...

${ }^{58}$ K.T. Liou, Role stress...

${ }^{59}$ P. Blau, Exchange...

${ }^{60} \mathrm{H}$. Levinson, Reciprocation...

${ }^{61}$ J.B. DeConinck, The effect of organizational justice, perceived organizational support, and perceived supervisor support on marketing employees’ level of trust, „Journal of Business Research” 63/2010; K. Krot, D. Lewicka, Zaufanie w organizacji innowacyjnej, C.H. Beck, 
Silna korelacja między zaufaniem do przełożonego a postrzeganym wsparciem otrzymywanym z jego strony była świadectwem tego, że są to podobne konstrukty. W ramach przeprowadzonej dodatkowo analizy czynnikowej stwierdzenia dotyczące wsparcia uzyskiwanego od przełożonego obok stwierdzeń odnoszących się do Skali Zaufania do Przełożonego wysycały oba wyróżnione czynniki w bardzo podobnym, umiarkowanym stopniu, wynoszącym odpowiednio w przypadku pierwszego stwierdzenia Skali Postrzeganego Wsparcia Przełożonego 0,40 i 0,52, drugiego - 0,51 i 0,33 oraz trzeciego - 0,44 i 0,45. Był to dowód na to, że zaufanie do przełożonego jest odrębnym konstruktem od postrzeganego wsparcia otrzymanego od przełożonego. Uzyskane wyniki są spójne z dotychczasowymi rezultatami badań, które wskazują na silne korelacje między postrzeganym przez pracowników wsparciem otrzymywanym od przełożonego a zaufaniem do jego osoby, potwierdzając jednocześnie odmienność obu tych konstruktów. Stanowią one kolejny dowód na to, że jednym z elementów wpływających na budowanie zaufania do przełożonego jest jego postawa wobec podwładnych, której efektem jest ich poczucie, że otrzymuje od niego wystarczający poziom wsparcia w pra$\mathrm{cy}^{62}$. Zgodnie z rezultatami płeć nie różnicuje badanych pod względem zaufania do przełożonego, co oznacza, że kobiety deklarują podobny poziom zaufania do menedżerów jak mężczyźni. Z kolei zaufanie do przełożonego nie ma związku z długością zatrudnienia w aktualnym miejscu pracy, jest negatywnie skorelowane ze stażem pracy i niezwiązane z wiekem. Zarówno staż pracy, jak i wiek są słabo negatywnie skorelowane z oceną integralności i życzliwości przełożonego.

Przeprowadzone badania niosą ze sobą liczne implikacje teoretyczne i praktyczne. Przede wszystkim wskazują na czynniki będące składowymi zaufania do przełożonego oraz podkreślają ich rolę dla dobrostanu pracowników oraz ich postawy wobec organizacji. W przeciwieństwie do modelu Mayer, Davis i Schoorman ${ }^{63}$ okazało się, że dla pracowników z Polski życzliwość i integralność, na którą składają się z jednej strony przychylność i sprzyjanie podwładnemu, a z drugiej uczciwość, szczerość i prawość, nie są odrębnymi czynnikami, ale raczej różnymi aspektami tego samego wymiaru. Różnią się one od oceny umiejętności i kompetencji posiadanych przez przełożonego, czyli elementów konstytuujących drugi wymiar Skali Zaufania do Przełożonego ${ }^{64}$.

Praktyczne implikacje zrealizowanych badań wskazują, na jakie elementy powinny kłaść nacisk osoby zarządzające w organizacjach oraz pracownicy działów

Warszawa 2016; S. Gurbuz, Some possible antecedents of military personnel organizational citizenship behawior, „Military Psychology” 21(2)/2009.

62 J.B. DeConinck, The effect of organizational justice...; P. Neves, A. Caetano, Social exchange processes...; M. Thomsen, S. Karsten, F.J. Oort, Social exchange in Dutch schools for vocational education and training: The role of teachers' trust in colleagues, the supervisor and higher management, „Educational Management Administration \& Leadership” 43(5)/2014.

${ }^{63}$ R.C. Mayer, J.H. Davis, F.D. Schoorman, An integrative model...

${ }^{64}$ Ibidem. 
zarządzania zasobami ludzkimi, jak również jakie cechy oraz atrybuty powinni posiadać menedżerowie, aby budować pozytywne relacje ze swoimi pracownikami oparte na wzajemnym zaufaniu jako podstawowym kapitale biznesowym organizacji.

Pomimo tego, że przeprowadzone badania miały poprzeczny, a nie podłużny charakter, czyli nie przedstawiają relacji między zmiennymi w porządku przyczynowo-skutkowym, to z dużym prawdopodobieństwem można uznać, iż zgodnie z otrzymanymi zależnościami brak zaufania do przełożonego oddziałuje pozytywnie na chęć opuszczenia organizacji, co jest również zgodne z powszechnymi przekonaniami funkcjonującymi w świadomości społecznej, „że przychodzi się do organizacji, a odchodzi się od przełożonego”. W związku z tym elementem strategii zarządzania zasobami ludzkimi każdej organizacji, której celem jest utrzymanie w miejscu pracy najlepszych pracowników powinno być dbanie o zatrudnianie menedżerów posiadających odpowiednie cechy, a z drugiej strony prowadzenie polityki personalnej ukierunkowanej na rozwój takich kompetencji i predyspozycji, które ułatwiają kształtowanie więzi z podwładnymi, opierających się na zaufaniu. Właściwym narzędziem do realizacji tych celów może być kształtowanie kultury organizacyjnej opartej na zaufaniu, budowaniu w kadrze zarządzającej - poprzez szkolenia, warsztaty, treningi czy coaching - świadomości znaczenia zaufania w relacjach z podwładnymi oraz rozwijaniu u nich cech i predyspozycji ułatwiających budowanie przez nich autorytetu jako osób godnych zaufania. W perspektywie selekcyjno-rekrutacyjnej może to być korzystanie z referencji osób będących podwładnymi w historii zatrudnienia danego kandydata do pracy czy stosowanie takich narzędzi, jak Assessment Center, które sprawdzają kompetencje oraz cechy kandydata związane z budowaniem zaufania do własnej osoby.

Przeprowadzone badania mają wstępny charakter. Dalsze prace dotyczące Skali Zaufania do Przełożonego powinny być skoncentrowane na standaryzacji tego narzędzia poprzez realizację projektu badawczego na reprezentatywnej próbie pracowników z Polski.

\section{Literatura}

Argyris C., Integrating the individual and the organization, John Wiley \& Sons, Inc., New York 1964.

Armeli S., Eisenberger R., Fasolo P., Lynch P., Perceived organizational support and police performance: The moderating influence of socio-emotional needs, „Journal of Applied Psychology" 83/1998.

Aryee S., Budhwar P.S., Xiong Chen Z., Trust as a mediator of the relationship between organizational justice and work outcomes: Test of a social exchange model, „Journal of Organizational Behaviour” 23/2002.

Blau P., Exchange and power in social life, Wiley, New York 1964. 
Byrne B.M., Structural equation modeling with EQS and EQS/Windows, Sage Publications, Thousand Oaks 1994.

Chiles T.H., McMackin J.F., Integrating variable risk preferences, trust, and transaction cost economics, „Academy of Management Review” 21(1)/1996.

Chirkowska-Smolak T., Grobelny J., Konstrukcja i wstępna analiza psychometryczna Kwestionariusza Postrzeganego Stresu w Pracy (PSwP), „Czasopismo Psychologiczne” 22(1)/2016.

Chirkowska-Smolak T., Wnuk M., Lojalność pracowników wobec organizacji - operacjonalizacja pojęcia oraz weryfikacja psychometryczna Skali Lojalności Wobec Organizacji - badania pilotażowe, „Organizacja i Kierowanie” 183(4)/2018.

Clark M.C., Payne R.L., The nature and structure of workers’trust in management, „Journal of Organisational Behavior” 18/1997.

Colquitt J.A., Scott B.A., LePine J.A., Trust, trustworthiness, and trust propensity: A meta-analytic test of their unique relationships with risk taking and job performance, „Journal of Applied Psychology" 92/2007.

Currall S.C., Judge T.A., Measuring trust between organizational boundary role persons, „Organizational Behavior and Human Decision Processes” vol. 64, no. 2.

DeConinck J.B., The effect of organizational justice, perceived organizational support, and perceived supervisor support on marketing employees' level of trust, „Journal of Business Research” 63/2010.

DeConinck J.B., The effect of organizational justice, perceived organizational support, and perceived supervisor support on marketing employees' level of trust, „Journal of Business Research” 63/2010.

Dietz G., Hartog D.N., Measuring trust inside organisations, „Personnel Review” 35/2006.

Dirks K.T., Ferrin D.L., Trust in leadership: Metaanalytic findings and implications for research and practice, „Journal of Applied Psychology” 87/2002.

Eisenberger R., Hungtington R., Hutchison S., Sowa D., Perceived organizational support, „Journal of Applied Psychology” 71(3)/1986.

Frost T., Stimpson D.V., Maughan N.R.C., Some correlates of trust, „Journal of Psychology" 99(1)/1978.

Gambetta D., Can we trust trust?, w: D. Gambetta (red.), Trust: Making and Breaking Cooperative Relations, Basil Blackwell, Oxford 1988.

Gouldner A.W., The norm of reciprocity: A preliminary statement, „American Sociological Review” 25(2)/1960.

Gurbuz S., Some possible antecedents of military personnel organizational citizenship behawior, „Military Psychology” 21(2)/2009.

Hornowska E., Testy psychologiczne teoria i praktyka, Wydawnictwo Naukowe Scholar, Warszawa 2017.

https://www.edelman.com/trust2017/.

Krot K., Lewicka D., Zaufanie w organizacji innowacyjnej, C.H. Beck, Warszawa 2016.

Larzelere R.E., Huston T.L., The dyadic trust scale: Toward understanding interpersonal trust in close relationships, „Journal of Marriage and the Family” 42(3)1980.

Levinson H., Reciprocation: The relationship between man and organization, „Administrative Science Quarterly” 9(4)/2001.

Li A.N., Tan H.H., What happens when you trust your supervisor? Mediators of individual performance in trust relationships, „Journal of Organizational Behavior” 34(3)/2013. 
Liou K.T., Role stress and job stress among detention care workers, „Criminal Justice and Behavior” vol. 22(4), 1995.

Mayer R.C., Davis J.H., Schoorman F.D., An integrative model of organizational trust, „Academy of Management Review” 20/1995.

Mulki J.P., Jaramillo F. Locander W.B., Effects of ethical climate and supervisory trust on salesperson's job attitudes and intentions to quit, „Journal of Personal Selling and Sales Management” 86(5)/2006.

Mulki J.P., Jaramillo F., Locander W.B., Effects of Ethical Climate and Supervisory Trust on Salesperson's Job Attitudes and Intentions to Quit, „Journal of Personal Selling \& Sales Management” 26(1)/2006.

Mulki J.P., Locander W.B., Marshall G.W., Harris E.G., Hensel J., Workplace isolation, salesperson commitment, and job performance, „Journal of Personal Selling \& Sales Management” 28(1)/2008.

Neves P., Caetano A., Social exchange processes in organizational change: The roles of trust and control, „Journal of Change Management” 4(6)/2006.

Neves P., Caetano A., Social exchange processes in organizational change: The roles of trust and control, ,Journal of Change Management” 6(4)/(2006).

Pomirleanu N., John-Mariadoss B., The influence of organizational and functional support on the development of salesperson job satisfaction, „Journal of Personal Selling and Sales Management” 35(1)/2015.

Rich G.A., The sales manager as a role model: Effects on trust, job satisfaction, and performance of salespeople, „Academy of Marketing Science” 25(4)/1997.

Robinson S.L., Trust and breach of the psychological contract, „Administrative Science Quarterly” 41(4)/1996.

Rotter J.B., A new scale for measurement of interpersonal trust, „Journal of Personality” 35(4)/1967.

Rousseau D.M., Sitkin S.B., Burt R.S., Camerer C., Not so different after all: A cross-discipline view of trust. "Academy of Management Review” 23(3)/1998.

Schriesheim C., Castro S., Cogliser C., Leader-member exchange (LMX) research: A comprehensive review of theory, measurement, and data-analytic procedures, „Leadership Quarterly” 10/1999.

Shockley-Zalabak P., Ellis K., Winograd G., Organizational trust: What it means, why it matters, „Organizational Development Journal” 18(4)/2000.

Steiger J.H., Structural model evaluation and modification: An interval estimation approach, „Multivariate Behavioral Research” 25(2)/1990.

Tan H.H., Tan C.S.F., Toward the differentiation of trust in supervisor and trust in organization, „Genetic, Social, and General Psychology Monographs” 126(2)/2000.

Thomsen M., Karsten S., Oort F.J., Social exchange in Dutch schools for vocational education and training: The role of teachers'trust in colleagues, the supervisor and higher management, „Educational Management Administration \& Leadership” 43(5)/2014.

Wnuk M., Psychometric evaluation of the Gratitude Toward Organization Scale, „Central European Management Journal” 28(2)/2020.

Wnuk M., Spirituality and job satisfaction. Mediating role of stress, gratitude towards organization and trust in supervisor. Moderating role of religious practices, „Modern Management Review” 23(4)/ 2018.

Wnuk M., Wdzięczność i lojalność wobec organizacji jako istotne elementy wymiany pracownik-organizacja, „Zarządzanie Zasobami Ludzkimi” 118(5)/ 2017. 
Yücel I., Examining the relationships among job satisfaction, organizational commitment, and turnover intention: An empirical study, „International Journal of Business and Management" 7/2012.

Zand D.E., Trust and managerial problem solving, „Administrative Science Quarterly” 17(2)/1972. 
